\title{
Radioactivity Levels and Soil-to-Plant Transfer Factor of Natural Radionuclides from Protectorate Area in Aswan, Egypt
}

\author{
S. Harb ${ }^{1}$, A. H. El-Kamel' ${ }^{2}$, A. I. Abd El-Mageed ${ }^{2}$, A. Abbady ${ }^{1}$, W. Rashed ${ }^{2}$ \\ ${ }^{1}$ Physics Department, Faculty of Science, South Valley University, Qena, Egypt \\ ${ }^{2}$ Physics Department, Faculty of Science, Assiut University, Assiut, Egypt \\ Email: s.harb@ymail.com
}

Received October 26, 2013; revised November 30, 2013; accepted December 11, 2013

Copyright (C) 2014 S. Harb et al. This is an open access article distributed under the Creative Commons Attribution License, which permits unrestricted use, distribution, and reproduction in any medium, provided the original work is properly cited. In accordance of the Creative Commons Attribution License all Copyrights (C) 2014 are reserved for SCIRP and the owner of the intellectual property S. Harb et al. All Copyright (C) 2014 are guarded by law and by SCIRP as a guardian.

\section{ABSTRACT}

The aim of this study is to determine the transfer factor soil-to-plant and to assess the concentration level of natural and artificial radionuclide $\left({ }^{238} \mathrm{U},{ }^{226} \mathrm{Ra},{ }^{228} \mathrm{Ra},{ }^{232} \mathrm{Th},{ }^{40} \mathrm{~K}\right.$ and $\left.{ }^{137} \mathrm{Cs}\right)$ in samples from Saluga and Ghazal Protectorate area in Aswan, Egypt, by using High Pure Germanium detector (HPGe) Environmental Radioactivity Measurements Labrotary in faculty of science Qena. Reported values for natural radionuclides ranged from 8.81 \pm 0.64 to $28.88 \pm 2.10$, from $6.98 \pm 0.51$ to $26.01 \pm 1.89$, from $12.29 \pm 0.89$ to $33.32 \pm 2.43$, from $12.53 \pm 0.91$ to $32.81 \pm 2.39$ and from $383.90 \pm 27.95$ to $711.98 \pm 51.83 \mathrm{~Bq} \cdot \mathrm{kg}^{-1}$ for ${ }^{238} \mathrm{U},{ }^{226} \mathrm{Ra},{ }^{228} \mathrm{Ra},{ }^{232} \mathrm{Th}$ and ${ }^{40} \mathrm{~K}$, respectively. ${ }^{137} \mathrm{Cs}$ activity concentration was found to be in the range from $0.36 \pm 0.03$ to $9.73 \pm 0.71 \mathrm{~Bq} \cdot \mathrm{kg}^{-1}$ and was calculated through transfer factor $\mathrm{TF}$ reported in this article.

\section{KEYWORDS}

\section{Natural Radionuclides; Transfer Factor; Plant; Soil; Protectorate Area}

\section{Introduction}

There is always a need to have baseline background level information about natural radionuclides and the radiological impact of radionuclides released to the terrestrial environment is usually predicted by mathematical models in which the transfer of radionuclides from soil to the plant is described with the transfer factor (TF). The most commonly encountered radionuclides are ${ }^{238} \mathrm{U},{ }^{232} \mathrm{Th}$, their decay products and ${ }^{40} \mathrm{~K}$. It is important to understand the behaviour of natural radionuclides in the environment (distribution pathways, mobility, transfers, etc.) because the information can be used as a natural analogue for the long-term behaviour of materials and processses in developing and testing models, and in obtaining the associated parameter values appropriate for radiological performance assessments [1].

Natural radionuclides occur in soil and they are incorporated metabolically into plants, and ultimately find their way into food and water. Manmade radionuclides behave in a similar manner, and worldwide contamination of the food chains by radionuclides produced during tests of nuclear weapons in the atmosphere has taken place during the past half century [2].

The study of the background level of ${ }^{137} \mathrm{Cs}$ in soil is really important as it is the main source of inventory of radionuclides into the food cycle. Its presence in soil would clearly indicate that the area under study might have received some fallout radioactivity in the past. It is extremely difficult, rather impossible, to exactly pinpoint the source of contamination.

Many studies on food contamination radionuclides in the environment and their transfer or pathway mechanism to plant, animals, and human population have been reported $[3,4]$. Considerable efforts are being made by many authors in many parts of the world to measure the activity of radionuclides in the food chain and to estimate the soil-plant transfer [5].

The uptake of radionuclides by plants from the soil is normally described by the transfer factor (TF) and the 
ratio of radionuclide concentrations in vegetation and soil. TFs can be based on the quantity of soil and expressed as the ratio of activity $\left(\mathrm{Bq} \cdot \mathrm{kg}^{-1}\right)$ in dry weight of plant to activity $\left(\mathrm{Bq} \cdot \mathrm{kg}^{-1}\right)$ in dry weight of soil [6], or can be based on surface area of soil and expressed as $\mathrm{Bq} \cdot \mathrm{kg}^{-1}$ dry weight of plant to $\mathrm{Bq} \cdot \mathrm{m}^{-2}$ in soil [7]. A wide range of TFs have been observed, mainly as a result of different soil and vegetation types and environmental conditions. Interactions between radionuclides and plants are very complicated and depend on many factors such as type and shape of plants, soil characteristics, behavior of radionuclides, climatic conditions, etc. [2].

These types of studies have attracted the interest of scientists global wide, especially in the developed countries in the last decade. Thus in Qena city, surveys on natural radiation and radioactivity measurements were organized, covering Upper Egypt since 1990. Obtained results are published in several articles, either published or in press. The main topic of these studies is determined natural radioactivity concentrations in soil, rocks, building materials, crops and water as well as exposure of the Egyptian population to terrestrial gamma radiation [5, 8-13].

\section{Materials and Methods}

\subsection{Sampling and Sample Preparation}

A total of 35 soil and 35 plant samples (different plants) were collected randomly from Saluga and Ghazal Protectorate area in Aswan, Egypt Figure 1. The masses of the collected soil samples varied between 250 and 350 $\mathrm{gm}$. The samples were ground, crushed to fine grain size of about 100 mesh and sieved in order to homogenize it and remove big size. The samples were then drying at

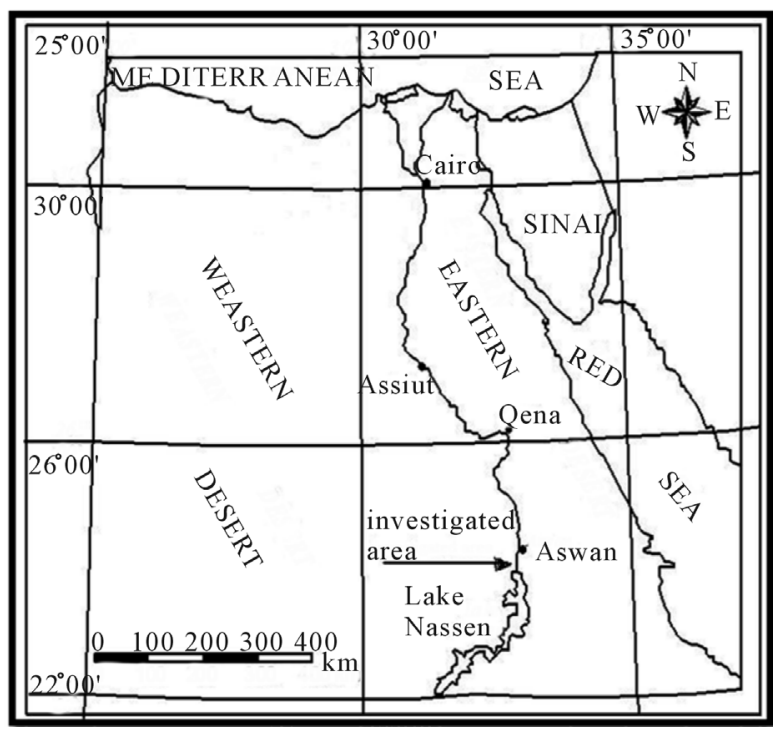

Figure 1. Map of the investigated area (Saluga and Ghazal Protectorate). $100^{\circ} \mathrm{C}$ for $48 \mathrm{~h}$ to ensure that moisture is completely removed. Plant samples were dried for $10-15 \mathrm{~h}$ at $100^{\circ} \mathrm{C}$ in an electric oven to obtain a constant dry weight. The sample was powdered, charred to get homogenize sample.

The representative powdered samples were packed in a standard plastic container $(7.5 \times 5.5 \mathrm{~cm})$ and after property tightening the threatened lid, the containers were sealed with adhesive tape and left for at least 4 weeks before counting by gamma spectrometry in order to ensure that the daughter products of ${ }^{226} \mathrm{Ra}$ up to ${ }^{210} \mathrm{~Pb}$ and of ${ }^{232} \mathrm{Th}$ up to ${ }^{208} \mathrm{~Pb}$ in secular equilibrium with their respective parent radionuclides and then the gamma ray spectrum was accumulated to up to $900 \mathrm{~min}$ [14] .

Saluga and Ghazal is one of the protectorate area in Egypt located on an area of five square kilometers in the River Nile are north of Aswan dam. It is a green area characterized by the sovereignty of some types of trees including acacia and approximately 94 different species of plants including those that solely grow in these islands. This protectorate is famous for its migrating birds, more than 60 bird species have been recorded, including species that have lived and reproduced in these islands since the ancient Pharaonic times, such as bittern, hoopoe and Egyptian geese.

\subsection{Experimental}

Radioactivity measurements of the samples were performed by gamma-ray spectrometry, using a coaxial high-purity germanium detector and multichannel analyzer; it has a potopeak relative efficiency of about $45 \%$ and an energy resolution of $1.91 \mathrm{keV}$ at the $1332 \mathrm{keV}$ gamma-ray transition of ${ }^{60} \mathrm{Co}$. The detector was calibrated in absolute efficiency using a mixed twelve radionuclides gamma standard QCY48 [13].

To reduce the counting background, a cylindrical lead shield with a fixed bottom and a movable cover, containing two inner concentric cylinders of copper and cadmium, was placed over the detector. The environmental $\gamma$-ray background at the laboratory site was determined using the same standard plastic container under identical measurement conditions from measurements prior, during and after the experiments, it was found that the background levels in the laboratory were maintained constant during the whole period of the measurements (two months).

\subsection{Calculation of Elemental Concentration}

Count rates for each detected photopeak and activity for each of the detected nuclides are calculated, the spectra were either analyzed with the computer program Maestro 2.1 (EG \& G ORTEC) or manually using a spreadsheet to calculate the natural radioactivity. The specific activity (in $\mathrm{Bq} \cdot \mathrm{kg}^{-1}$ ), $A_{E i}$ of a nuclide $i$. and for a peak at energy $E$, 
is given by:

$$
A_{E i}=\frac{N P}{t_{c} \cdot I_{\gamma}\left(E_{\gamma}\right) \cdot \varepsilon\left(E_{\gamma}\right) \cdot M}
$$

where $N P$ is the number of count in a given peak area corrected for background peaks of a peak at energy $E$, $\varepsilon\left(E_{\gamma}\right)$ the detection efficiency at energy $E, t$ is the counting time in second, $I_{\gamma}\left(E_{\gamma}\right)$ the number of gammas per disintegration of this nuclide for a transition at energy $E$, and $M$ is the mass in $\mathrm{kg}$ of the measured sample.

Assuming attainment the secular equilibrium in the uranium and thorium decay products series, the $\gamma$-ray transitions to measure the concentration of the assigned nuclides in the series[15], ${ }^{238} \mathrm{U}$ determined from ${ }^{234 \mathrm{~m}} \mathrm{~Pa}$ through $1001.03 \mathrm{keV}$, 226Ra was determined via its daughters $\left({ }^{214} \mathrm{~Pb}\right.$ and $\left.{ }^{214} \mathrm{Bi}\right)$ through the $351.93 \mathrm{keV}$ and $609.3 \mathrm{keV} \gamma$-lines, while the ${ }^{232} \mathrm{Th}$ was determined through the ${ }^{208} \mathrm{Tl}$ and ${ }^{212} \mathrm{~Pb}$ emissions at $583.19 \mathrm{keV}$ and $238.63 \mathrm{keV}$ respectively, but ${ }^{228} \mathrm{Ac}$ at $911.20 \mathrm{keV}$ was used to determined ${ }^{228}$ Ra. K-40 was determined from the $1460.83 \mathrm{keV} \gamma$-line, and a small peak found around the line 661.7 was used to determine the activity concentration of ${ }^{137} \mathrm{Cs}$. The spectra were either evaluated with the computer software programme Maestro (EG \& G ORTIC), or manually with the use of a spread sheet (Microsoft Excel) to calculate the natural radioactivity.

\subsection{Calculation of Statistical Error for Measurement Process}

To correct $A_{E i}$ to actual activity in sample, we must apply the necessary corrections to the count rate. Some typical corrections include:

1) Counter efficiency $=\varepsilon$

2) Emission probability of emitted radiation $=I$

To get the relative uncertainties of input value.

$$
\begin{aligned}
& \frac{u^{2}\left(A_{s}\right)}{A_{s}^{2}} \\
& =\frac{u^{2}(N P)}{(N P)^{2}}+\frac{u^{2}\left(t_{C}\right)}{\left(t_{C}^{2}\right)}+\frac{u^{2} I_{\gamma}\left(E_{\gamma}\right)}{I_{\gamma}^{2}\left(E_{\gamma}\right)}+\frac{u^{2} \varepsilon\left(E_{\gamma}\right)}{\varepsilon^{2}\left(E_{\gamma}\right)}+\frac{u^{2}(M)}{\left(M^{2}\right)}
\end{aligned}
$$

where $\frac{u(N P)}{(N P)}$ from spectra evaluation

$$
N P=N P-N_{0}
$$

where the $N P$ is net peak and $N_{0}$ is counting of background

\subsection{Transfer Factor}

Transfer factor (TF), which is the ratios of specific activities in plant and soil (in $\mathrm{Bq} \cdot \mathrm{kg}^{-1}$ dry weight plant part divided by $\mathrm{Bq} \cdot \mathrm{kg}^{-1}$ dry weight soil), can be used as an index for the accumulation of trace elements by plants or the transfer of elements from soil to plants[16,17].

The corresponding TF of different plants, relating the specific activity of a given radionuclide $\left({ }^{226} \mathrm{Ra}\right.$, ${ }^{228} \mathrm{Ra}$, ${ }^{232} \mathrm{Th}$ and ${ }^{40} \mathrm{~K}$ ) For each individual plant were calculated for all vegetation as,

$$
\begin{aligned}
& T F \\
& =\frac{\text { activity concentration of plant }\left(\mathrm{Bq} \cdot \mathrm{kg}^{-1} \text { dry weight }\right)}{\text { activity concentration of soil }\left(\mathrm{Bq} \cdot \mathrm{kg}^{-1} \text { dry weight }\right)}
\end{aligned}
$$

\section{Results and Discussions}

Table 1 summarizes mean values and ranges of the activity concentrations (Bq $\cdot \mathrm{kg}^{-1}$ dry weight) for ${ }^{238} \mathrm{U},{ }^{226} \mathrm{Ra}$, ${ }^{232} \mathrm{Th},{ }^{228} \mathrm{Ra},{ }^{40} \mathrm{~K}$ and ${ }^{137} \mathrm{Cs}$ and transfer factor in soil and plant samples from Saluga and Ghazal Protectorate area in Aswan, Egypt.

It can be seen in this table that the activity of Uranium series via exemplify ${ }^{238} \mathrm{U}$ and ${ }^{226} \mathrm{Ra}$ ranged from $8.81 \pm$ 0.64 to $28.88 \pm 2.10$ and from $6.98 \pm 0.51$ to $26.01 \pm 1.89$ $\mathrm{Bq} \cdot \mathrm{kg}^{-1}$ for ${ }^{238} \mathrm{U}$ and ${ }^{226} \mathrm{Ra}$ respectively.

The activity of ${ }^{232} \mathrm{Th}$ and ${ }^{228}$ Ra ranged from $12.53 \pm 0.91$ to $32.81 \pm 2.39$ and from $12.29 \pm 0.89$ to $33.32 \pm 2.43$ $\mathrm{Bq} \cdot \mathrm{kg}^{-1}$ respectively. The activity of ${ }^{40} \mathrm{~K}$ is seen to be the highest value than the other natural radionuclides, its values ranged from $383.90 \pm 27.95$ to $711.98 \pm 51.83 \mathrm{~Bq} \cdot \mathrm{kg}^{-1}$.

\begin{tabular}{|c|c|c|c|c|c|c|}
\hline \multirow{2}{*}{ Radio-nuclide } & \multicolumn{2}{|r|}{ Soil Samples } & \multicolumn{2}{|r|}{ Plant Samples } & \multicolumn{2}{|c|}{ Transfer Factor } \\
\hline & Mean Value & Range & Mean Value & Range & Mean Value & Range \\
\hline${ }^{238} \mathrm{U}$ & $19.02 \pm 1.43$ & $8.81 \pm 0.64-28.88 \pm 2.10$ & - & - & - & - \\
\hline${ }^{226} \mathrm{Ra}$ & $16.92 \pm 1.28$ & $6.98 \pm 0.51-26.01 \pm 1.89$ & $7.8 \pm 0.65$ & $1.36 \pm 0.10-17.58 \pm 1.28$ & 0.43 & $0.19-0.73$ \\
\hline${ }^{232} \mathrm{Th}$ & $21.96 \pm 1.66$ & $12.53 \pm 0.91-32.81 \pm 2.39$ & $6.94 \pm 0.60$ & $2.12 \pm 0.15-17.89 \pm 1.30$ & 0.31 & $0.09-0.88$ \\
\hline${ }^{228} \mathrm{Ra}$ & $21.93 \pm 1.65$ & $12.29 \pm 0.89-33.32 \pm 2.43$ & $7.12 \pm 0.61$ & $2.13 \pm 0.16-16.66 \pm 1.21$ & 0.32 & $0.10-0.76$ \\
\hline${ }^{40} \mathrm{~K}$ & $505.92 \pm 37.84$ & $383.90 \pm 27.95-711.98 \pm 51.83$ & $519.42 \pm 45.34$ & $156.86 \pm 11.42-1186.46 \pm 86.38$ & 1.06 & $0.31-2.95$ \\
\hline${ }^{137} \mathrm{Cs}$ & $1.90 \pm 0.20$ & $0.36 \pm 0.03-9.73 \pm 0.71$ & - & - & - & - \\
\hline
\end{tabular}
The activity of artificial radionuclide ${ }^{137} \mathrm{Cs}$ were found to fluctuated from $0.36 \pm 0.03$ to $9.73 \pm 0.71 \mathrm{~Bq} \cdot \mathrm{kg}^{-1}$.

Figure 2 shows the frequency distributions of activity

Table 1. Mean values and ranges of the activity concentrations $\left(\mathrm{Bq} \cdot \mathrm{kg}^{-1} \mathrm{dry}\right.$ weight) for ${ }^{238} \mathrm{U},{ }^{226} \mathrm{Ra},{ }^{232} \mathrm{Th},{ }^{228} \mathrm{Ra},{ }^{40} \mathrm{~K}$ and ${ }^{137} \mathrm{Cs}$ and transfer factor in soil and plant samples from Saluga and Ghazal Protectorate area in Aswan, Egypt. 


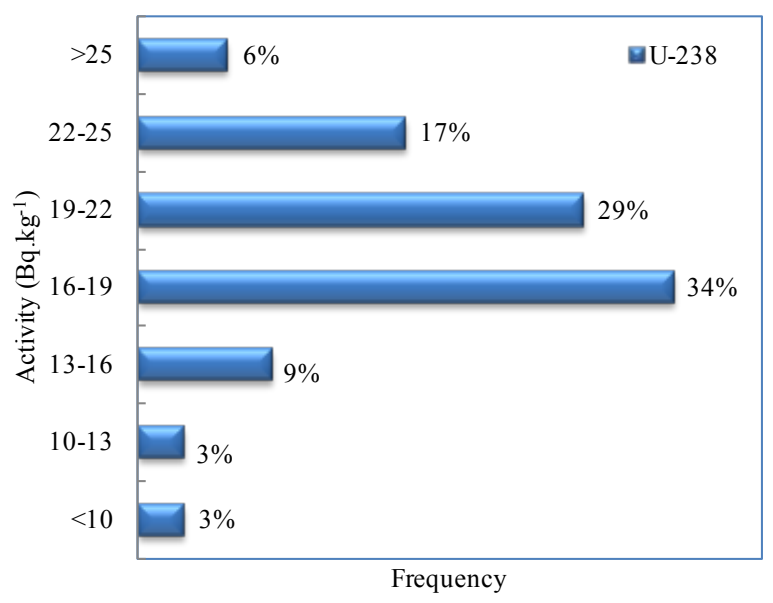

(a)

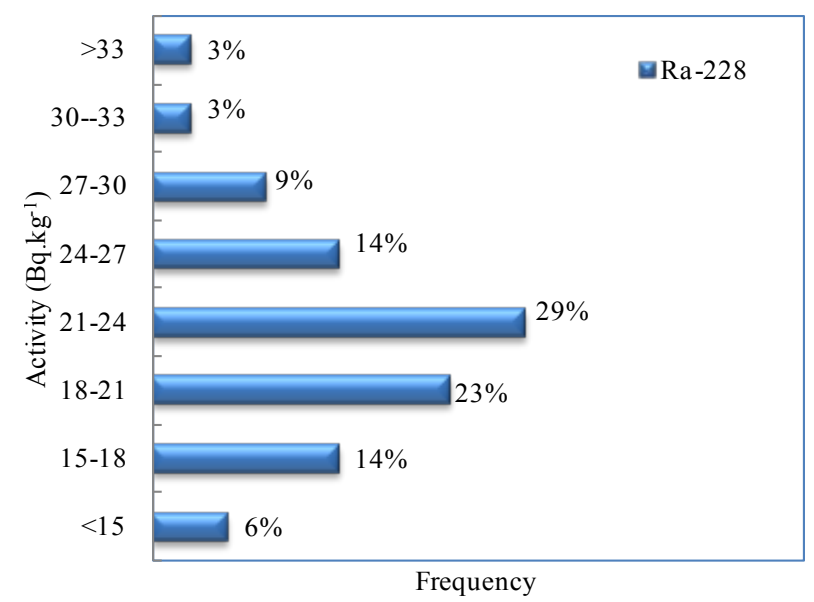

(c)

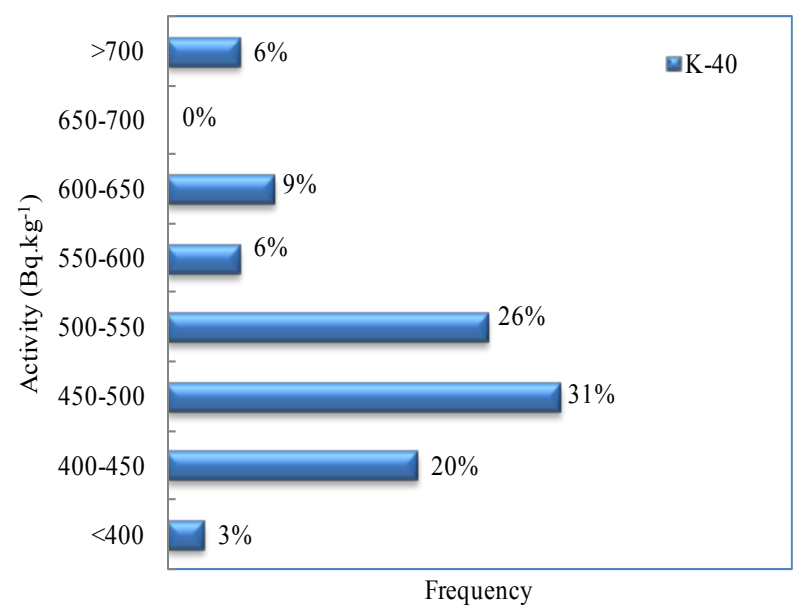

(e)

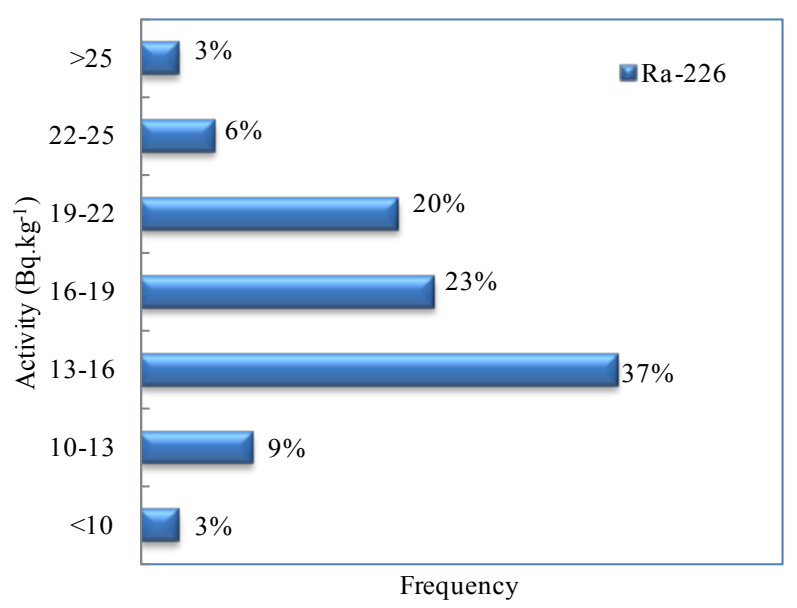

(b)

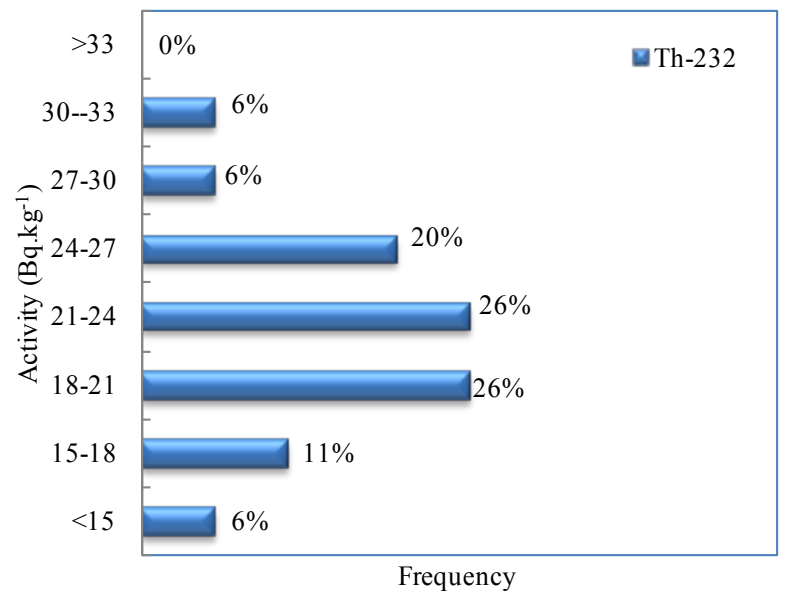

(d)

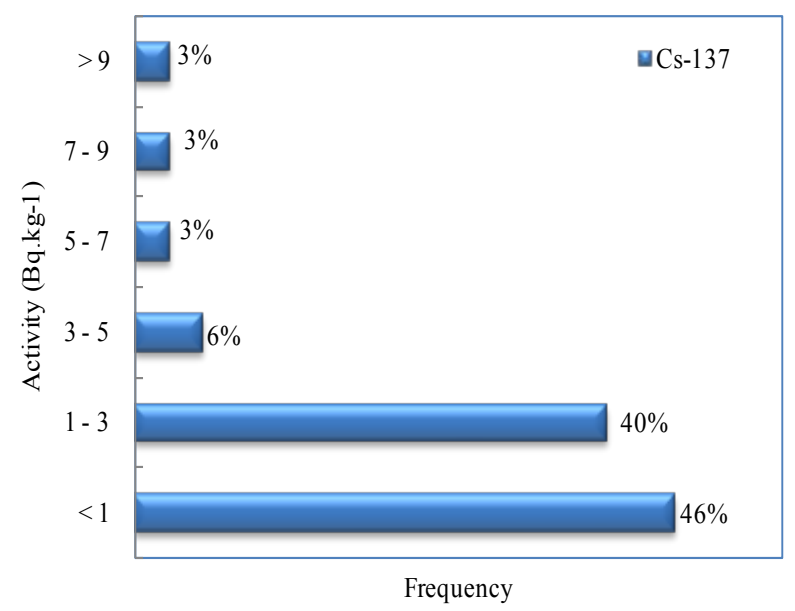

(f)

Figure 2. Frequency distributions of activity concentrations $\left(\mathrm{Bq} \cdot \mathrm{kg}^{-1}\right)$ in soil sample from Saluga and Ghazal Protectorate area in Aswan, Egypt for ${ }^{238} \mathrm{U},{ }^{226} \mathrm{Ra},{ }^{228} \mathrm{Ra},{ }^{232} \mathrm{Th},{ }^{40} \mathrm{~K}$ and ${ }^{137} \mathrm{Cs}$.

concentrations $\left(\mathrm{Bq} \cdot \mathrm{kg}^{-1}\right)$ in soil sample under investigation from Saluga and Ghazal Protectorate area in Aswan, Egypt for ${ }^{238} \mathrm{U},{ }^{226} \mathrm{Ra},{ }^{228} \mathrm{Ra},{ }^{232} \mathrm{Th},{ }^{40} \mathrm{~K}$ and ${ }^{137} \mathrm{Cs}$. From the figure it can be noticed that the activity concentration for more than $85 \%$ of soil sample ranged between 13 to 25 for ${ }^{238} \mathrm{U}$ and ${ }^{226} \mathrm{Ra}$, while ${ }^{232} \mathrm{Th}$ and ${ }^{228} \mathrm{Ra}$ more than $50 \%$ of samples under investigation ranged between 13 and 19 $\mathrm{Bq} \cdot \mathrm{kg}^{-1}$. More than $75 \%$ of soil samples ranged from 400 
to $550 \mathrm{~Bq} \cdot \mathrm{kg}^{-1}$ for ${ }^{40} \mathrm{~K}$, but ${ }^{137} \mathrm{Cs}$ much of $46 \%$ of samples under investigation to be less than $1 \mathrm{~Bq} \cdot \mathrm{kg}^{-1}$.

Figure 3 shows the concentration ratios that evaluated from the measured values of activity concentrations. The mean value ${ }^{226} \mathrm{Ra} /{ }^{238} \mathrm{U}$ ratios for different soil samples of

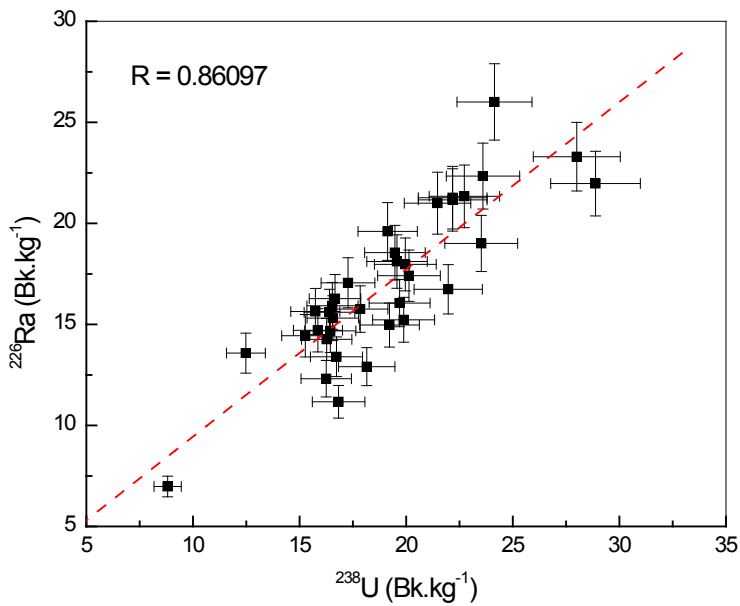

(a)

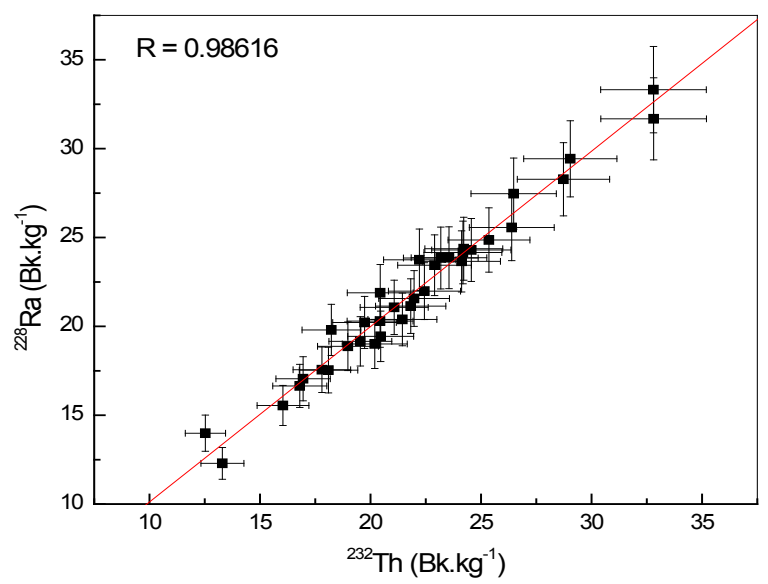

(c)

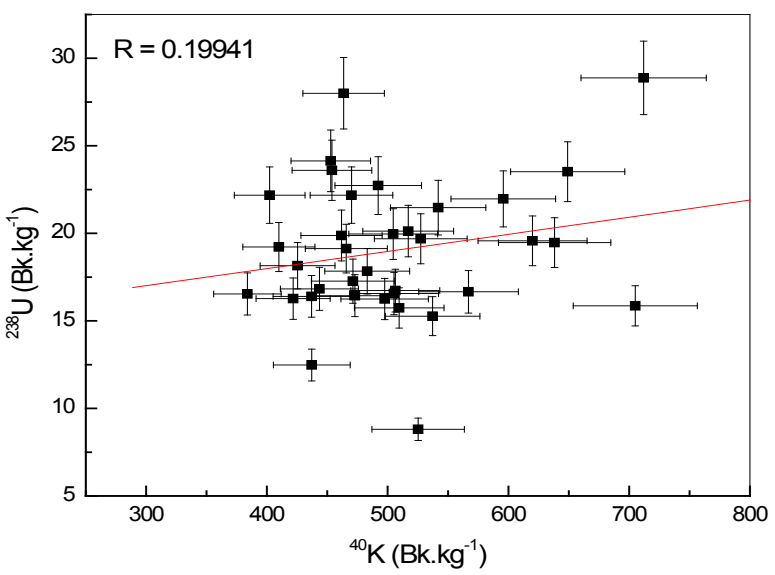

(e) protectorate is 0.86 that indicates the status of the radioactive secular equilibrium between ${ }^{226} \mathrm{Ra}$ and ${ }^{238} \mathrm{U}$ in these soils otherwise the mean ${ }^{228} \mathrm{Ra} /{ }^{232} \mathrm{Th}$ ratio is 0.99 referring to complete equilibrium between thorium series.

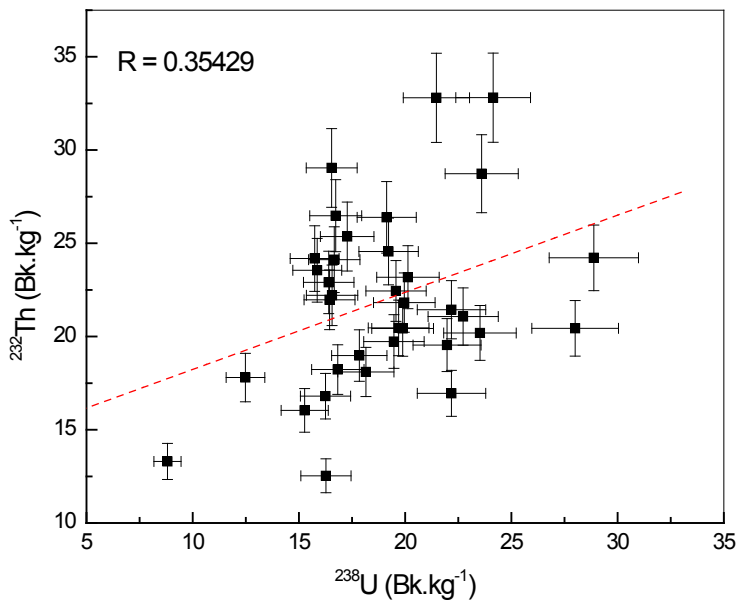

(b)

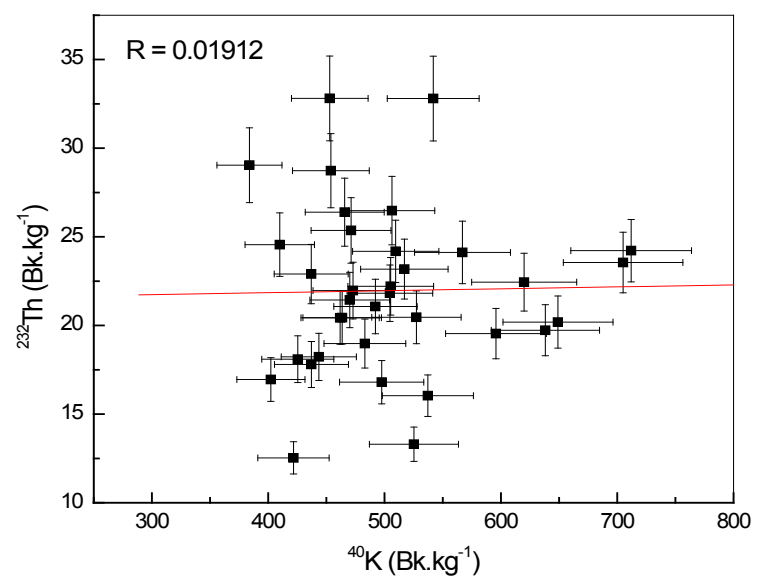

(d)

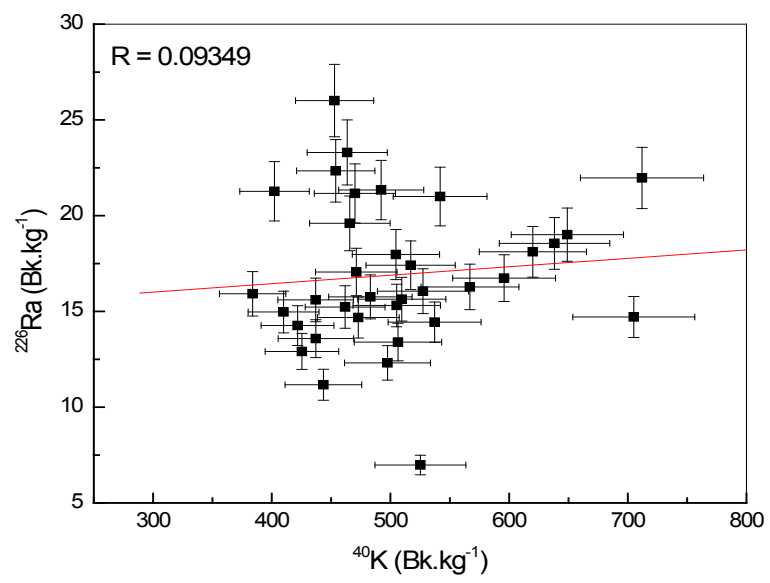

(f)

Figure 3. Elemental correlation between natural radionuclides in soil samples from Saluga and Ghazal Protectorate area in Aswan, Egypt. 
The mean ratios ${ }^{232} \mathrm{Th} /{ }^{238} \mathrm{U},{ }^{232} \mathrm{Th} /{ }^{40} \mathrm{~K},{ }^{238} \mathrm{U} /{ }^{40} \mathrm{~K}$ and ${ }^{226} \mathrm{Ra} /{ }^{40} \mathrm{~K}$ are $0.35,0.02,0.199$ and 0.09 for the Protectorate soil. The highly significant correlation occurring between uranium and thorium is consistent with the geochemical behaviour of their complexes, namely, the tendency of uranium and thorium to concentrate in the fluid phase during magma tic differentiation. Uranium and thorium, with their daughters present in rock and soil, are the main contributors to the absorbed dose rate in air and, hence, to the dose absorbed by the population [18]. Radioactivity in soil results from the rock from which it is derived. It is diminished by leaching of water, diluted by increased porosity and by added water and organic matter, and augmented by sorption and precipitation of radionuclides from incoming water.

The soil on the top that contributes significantly to background dose. Background concentrations of radionuclides in soil vary because of many factors. Soil may have been produced from the weathered top layer of still-intact bedrock below or transported laterally from the same rock unit or type some distance away. One of methods of transport is natural phenomena such as

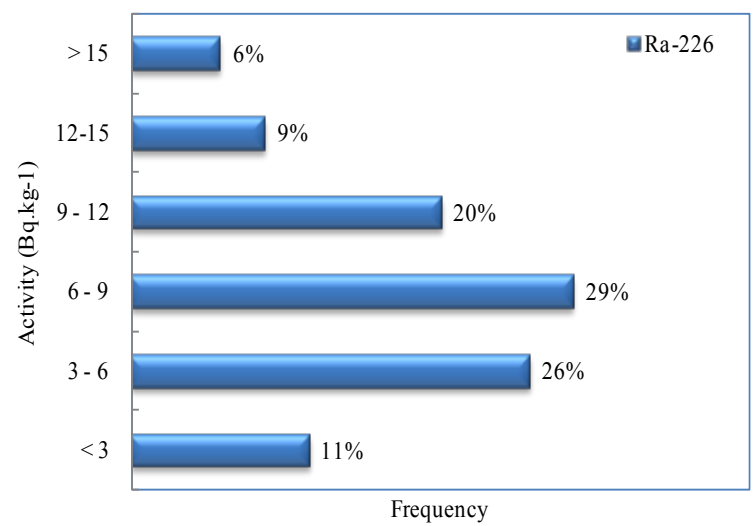

(a)

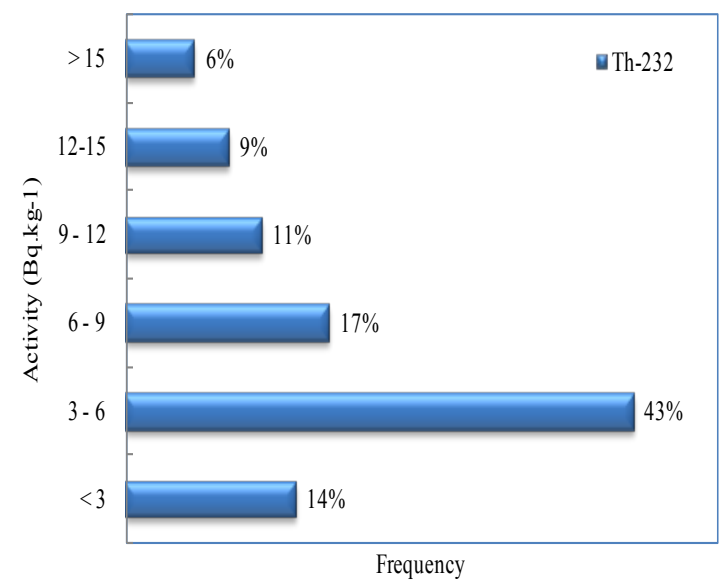

(c) earthquakes, volcanoes, and change in soil composition from flooding.

The concentrations of the radioisotopes in different plant samples are reported in $\mathrm{Bq} \cdot \mathrm{kg}^{-1}$ of dry weight as shown in Table 1. The concentration of ${ }^{226} \mathrm{Ra}$ ranged from $1.36 \pm 0.10$ to $17.58 \pm 1.28$ while both ${ }^{228} \mathrm{Ra}$ and ${ }^{232} \mathrm{Th}$ had the same range of activity concentrations from $2.12 \pm 0.15$ to $17.89 \pm 1.30$; while ${ }^{232}$ Th concentration values approximation have the same extent, ranged from $2.13 \pm 0.16$ to $16.66 \pm 1.21$. For ${ }^{40} \mathrm{~K}$, the concentrations ranged from $156.86 \pm 11.42$ to $1186.46 \pm 86.38 \mathrm{~Bq} \cdot \mathrm{kg}^{-1}$.

Figure 4 shows the frequency distributions of activity concentrations $\left(\mathrm{Bq} \cdot \mathrm{kg}^{-1}\right.$ for dry weight) in plant sample from Saluga and Ghazal Protectorate area in Aswan, Egypt for ${ }^{226} \mathrm{Ra},{ }^{228} \mathrm{Ra},{ }^{232} \mathrm{Th}$ and ${ }^{40} \mathrm{~K}$. From the figure it is clear that the activity concentration for more than $70 \%$ of plant sample ranged between 3 to $12 \mathrm{~Bq} \cdot \mathrm{kg}^{-1}$ for dry weight for ${ }^{226} \mathrm{Ra},{ }^{228} \mathrm{Ra}$ and ${ }^{232} \mathrm{Th}$. For ${ }^{40} \mathrm{~K}$ much of $29 \%$ of samples under investigation to be ranged from 200 to $400 \mathrm{~Bq} \cdot \mathrm{kg}^{-1}$ for dry weight.

Figure 5 shows the concentration ratios that evaluated from the measured values of activity concentrations. The

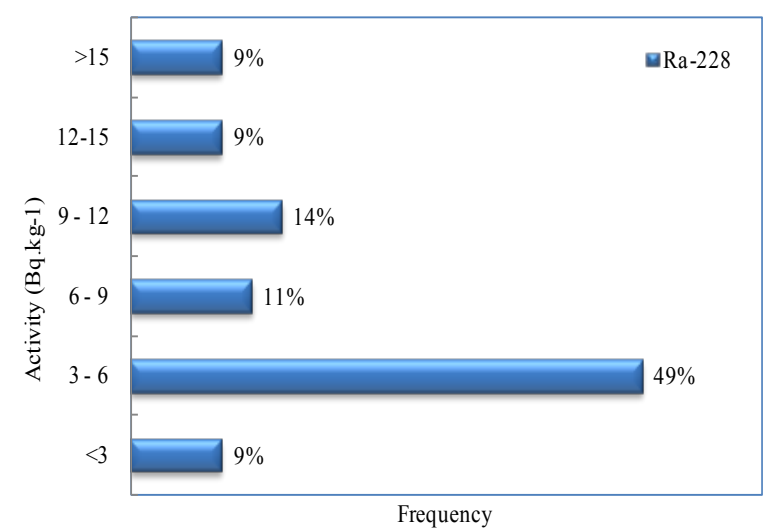

(b)

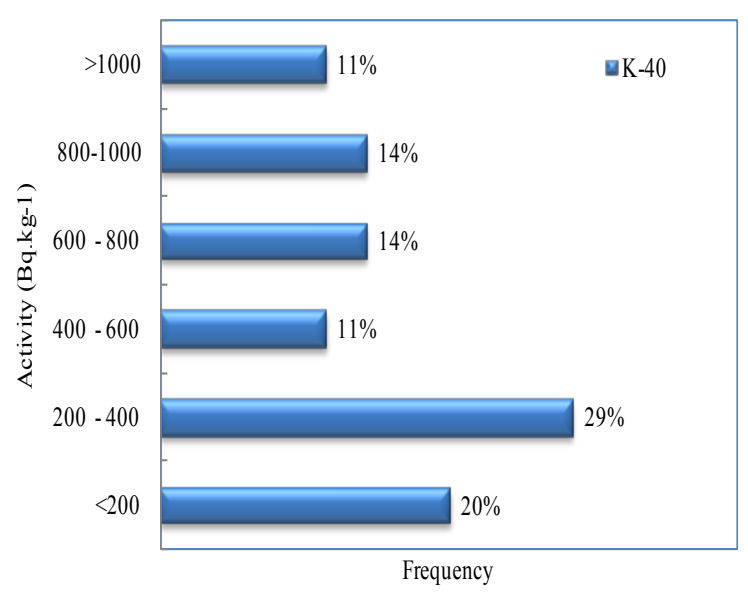

(d)

Figure 4. Frequency distribution of activity concentrations $\left(\mathrm{Bq}^{\circ} \mathrm{kg}^{-1}\right)$ in plant from Saluga and Ghazal Protectorate area in Aswan, Egypt for ${ }^{226} \mathrm{Ra},{ }^{228} \mathrm{Ra},{ }^{232} \mathrm{Th}$ and ${ }^{40} \mathrm{~K}$. 


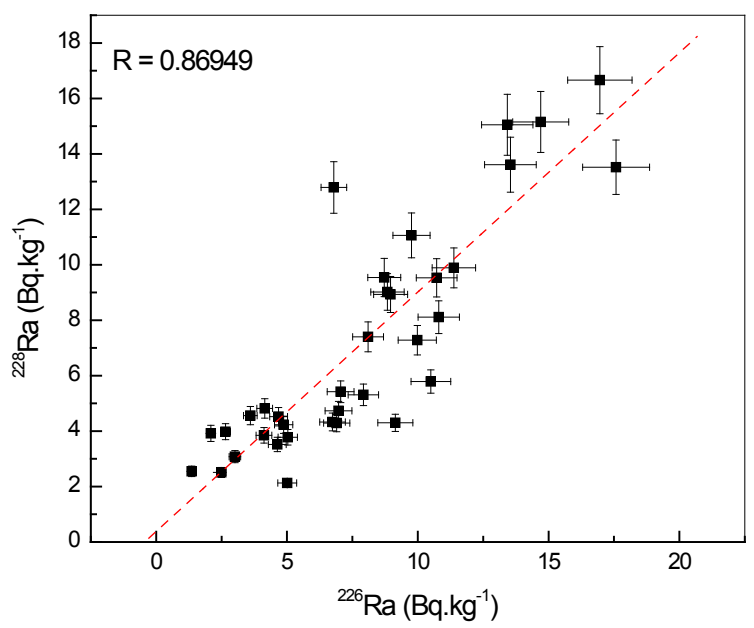

(a)

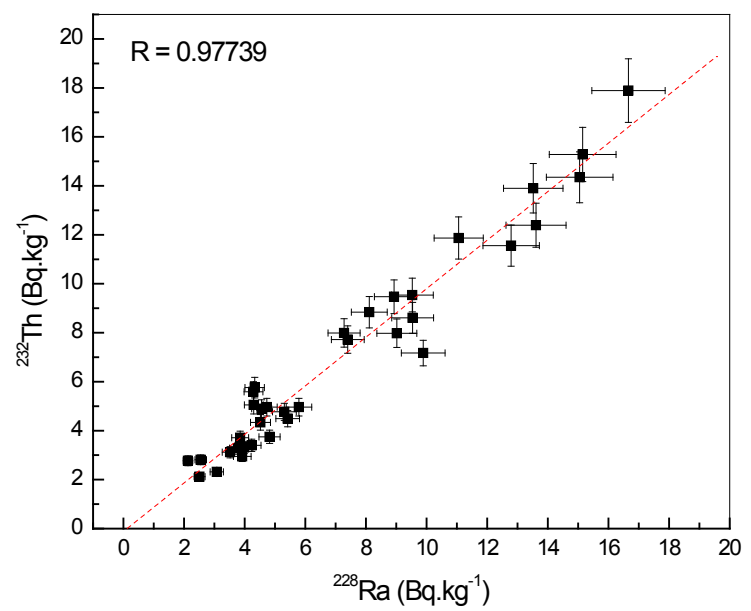

(c)

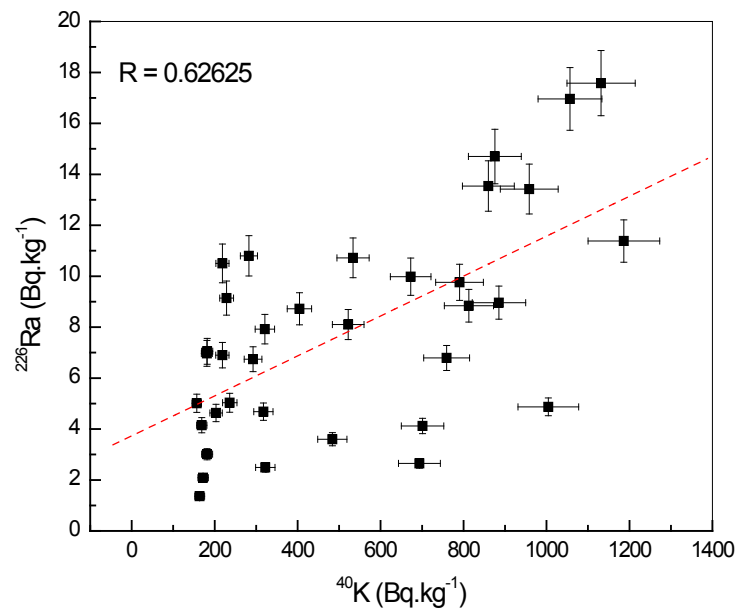

(e)

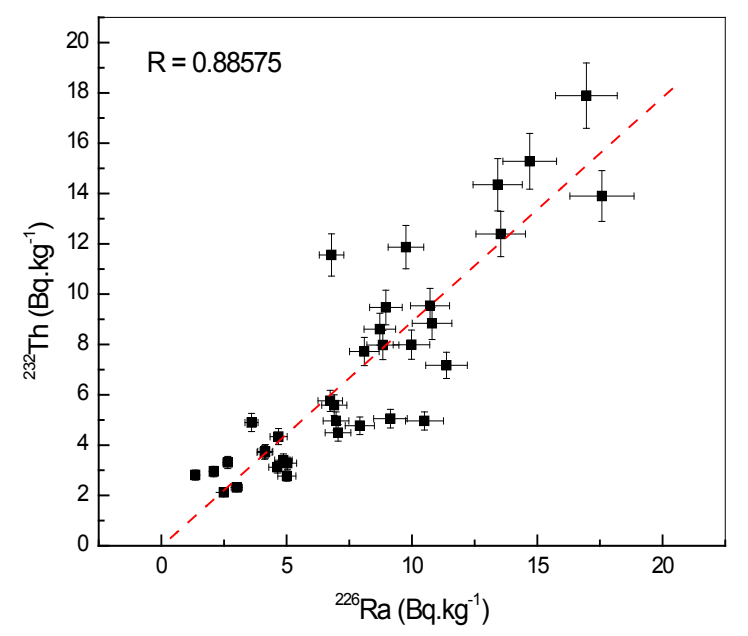

(b)

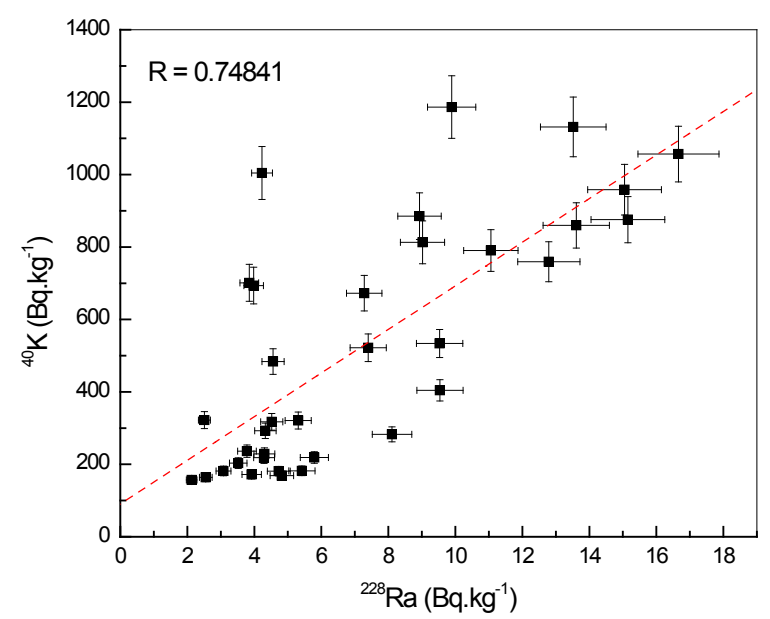

(d)

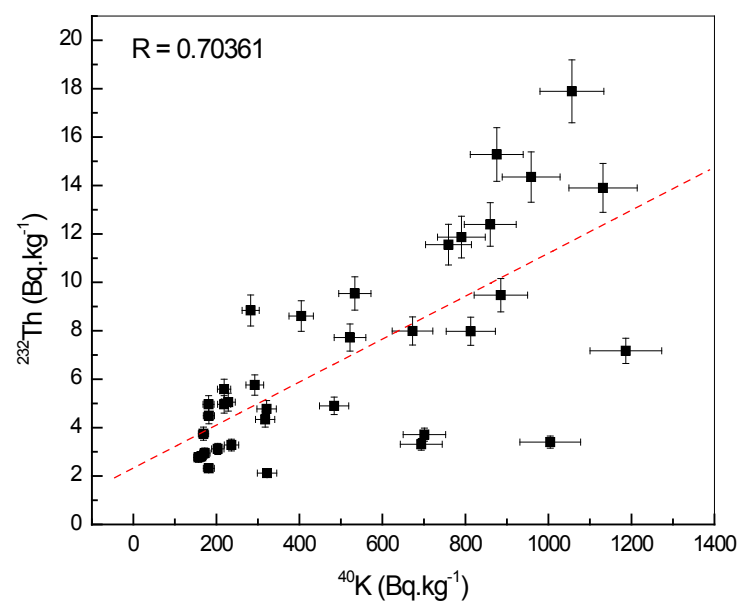

(f)

Figure 5. Elemental correlation between natural radionuclides in plant samples from Saluga and Ghazal Protectorate area in Aswan, Egypt.

mean ratio ${ }^{228} \mathrm{Ra} /{ }^{226} \mathrm{Ra},{ }^{232} \mathrm{Th} /{ }^{226} \mathrm{Ra},{ }^{232} \mathrm{Th} /{ }^{228} \mathrm{Ra},{ }^{40} \mathrm{~K} /{ }^{228} \mathrm{Ra}$, ${ }^{226} \mathrm{Ra} /{ }^{40} \mathrm{~K}$ and ${ }^{232} \mathrm{Th} /{ }^{40} \mathrm{~K}$ are $0.87,0.89,0.98,0.75,0.63$ and 0.70 for the Protectorate soil, the mean values
${ }^{232} \mathrm{Th} /{ }^{228} \mathrm{Ra}$ ratios for different plant samples of Protectorate is 0.98 that indicate the status of the radioactive secular equilibrium in thorium series. 
The transfer factors (TF) for ${ }^{226} \mathrm{Ra},{ }^{232} \mathrm{Th}$ and its daughter ${ }^{228} \mathrm{Ra}$ and ${ }^{40} \mathrm{~K}$ were obtained soil-in plant samples growing in Saluga and Ghazal Protectorate area in Aswan, Egypt.

The TF in this ecosystem is as high as 0.19 to 0.73 for ${ }^{226} \mathrm{Ra}, 0.09$ to 0.88 for ${ }^{232} \mathrm{Th}, 0.10$ to 0.76 for ${ }^{228} \mathrm{Ra}$ and 0.31 to 2.95 for ${ }^{40} \mathrm{~K}$ as listed in Table 1 . The high value of $\mathrm{TF}$ is attributed to the abundance of the organic matter in the forest soils. The rapid recycling of natural radionuclides through the soil-plant system of this undisturbed multistoried ecosystem suggests the existence of an internal cycling that help the accumulation of natural radionuclides in this ecosystem.

\section{Conclusions}

The analytical results provide that all samples of this particular area significantly contain three radioactive isotopes $\left({ }^{238} \mathrm{U},{ }^{232} \mathrm{Th}\right.$ and $\left.{ }^{40} \mathrm{~K}\right)$, all of which probably originated in the ancient craters at the Saluga and Ghazal Protectorate area in addition of the presence of ${ }^{137} \mathrm{Cs}$ in the soil. The mean values of activity concentrations of these elements $\left(\mathrm{Bq} \cdot \mathrm{kg}^{-1}\right)$ in soil samples are 19.02 \pm 1.43 , $16.92 \pm 1.28,21.96 \pm 1.66,21.93 \pm 1.65,505.92 \pm 37.84$ and $1.90 \pm 0.20$ for ${ }^{238} \mathrm{U},{ }^{226} \mathrm{Ra},{ }^{232} \mathrm{Th},{ }^{228} \mathrm{Ra},{ }^{40} \mathrm{~K}$ and ${ }^{137} \mathrm{Cs}$, respectively.

The mean values of activity concentrations for ${ }^{238} \mathrm{U}$, ${ }^{226} \mathrm{Ra},{ }^{232} \mathrm{Th},{ }^{228} \mathrm{Ra},{ }^{40} \mathrm{~K}$ and ${ }^{137} \mathrm{Cs}$ were $19.02 \pm 1.43$, $16.92 \pm 1.28,21.96 \pm 1.66,21.93 \pm 1.65,505.92 \pm 37.84$ and $1.90 \pm 0.20 \mathrm{~Bq} \cdot \mathrm{kg}^{-1}$, respectively. The transfer factors (TF) for ${ }^{226} \mathrm{Ra},{ }^{232} \mathrm{Th},{ }^{228} \mathrm{Ra}$ and ${ }^{40} \mathrm{~K}$ were $0.43,0.31$, 0.32 and 1.06 , respectively.

\section{REFERENCES}

[1] F. Vera Tome, M. P. Blanco Rodríguez and J. C. Lozano, "Soil-to-Plant Transfer Factors for Natural Radionuclides and Stable Elements in a Mediterranean Area" Journal of Environmental Radioactivity, Vol. 65, 2003, pp. 161-175. http://dx.doi.org/10.1016/S0265-931X(02)00094-2

[2] S. Golmakani, V. M. ahabi Moghaddam and T. Hosseini, "Factors Affecting the Transfer of Radionuclides from the Environment to Plants," Radiation Protection Dosimetry, Vol. 130, No. 3, 2008, pp. 1-8.

[3] International Commission on Radiological Protection (ICRP), "Age-Dependant Dose to Member of the Public from Intake of Radionuclides. Part 11. Publication-67," Pergamon Press, Oxford, 1993

[4] M. I. Gaso, N. Segovia, M. L. Cervantes, T. Herrera, E. Perez-Silva, and E. Acosta, "Internal Radiation Dose from ${ }^{137}$ Cs Due to the Consumption of Mushrooms from a Mexican Temperate Mixed Forest," Radiation Protection Dosimetry, Vol. 87, 2000, pp. 213-216. http://dx.doi.org/10.1093/oxfordjournals.rpd.a033000

[5] A. Abbady, "Level of Natural Radionuclides in Foodstuffs and Resultant Annual Ingestion Radiation Dose,"
Nuclear Science and Techniques, Vo1. 17, No. 5, 2006, pp. 297-300.

[6] International Atomic Energy Agency (IAEA), "Handbook of Parameter Values for the Prediction of Radionuclide Transfer in Temperate Environments," Technical Report Series No. 364, Vienna, 1994

[7] M. J. Frissel, "Protocol for the Experimental Determination of Soil to Plant Transfer Factors (Concentration Ratios) to Be Used in Radiological Assessment Models," UIR Newsletter, Vol. 28, 1997, pp. 5-8.

[8] A. Abbady, N. K, Ahmed, A. H. El-Kamel, F. Steinhasular, A. M. El-Arabi, "Field Measurements of Radon-222 in Soil Using Alphaguard and E-PERM Electret," Nuclear Science Journal, Vol. 37, No. 2, 2000, pp. 122-134.

[9] A. M. El-Arabi, "Natural Radioactivity in Sand Used in Thermal Therapy at the Red Sea Coast," Journal of Environmental Radioactivity, Vol. 81, 2005, pp. 11-19. http://dx.doi.org/10.1016/j.jenvrad.2004.11.002

[10] A. M. El-Arabi, N. K. Ahmed, A. H. El-Kamel, "Gamma Spectroscopic Analysis of Powdered Granite Samples in Some Eastern Desert'S Areas," Arab Journal of Nuclear Science and Applications, Vol. 34, 2001, pp. 245-255.

[11] N. K. Ahmed, A. M. El Arabi, H. M. Mahmoud and K. Salahel-din, "Measurement of Natural Radioactivity and Its Significant Hazards of Some Hematite Samples in Eastern Desert, Egypt," Building and Environment, Vol. 42, 2007, pp. 2263-2267.

[12] M. H. Said, A. Abbady, A. H. El-Kamel and A. M. El-Arabi, "Natural Radioactivity of Granite Rocks in Wadi Qena," Radiation Physics and Chemistry, Vol. 44 No. 1/2, 1994, p. 95. http://dx.doi.org/10.1016/0969-806X(94)90112-0

[13] S. Harb, A. H. El-Kamel, A. I. Abd El-Mageed, A. Abbady and W. Rashed, "Concentration of U-238, U-235, Ra-226, Ra-228, Th-232 and K-40 for Some Igneous Rock Samples in Eastern Desert of Egypt," The 3rd Environmental Physics Congress, Aswan, 2008, pp. 215222.

[14] M. M. Isam Salih, H. B. L. Pettersson and E. Lund, "Uranium and Thorium Series Radionuclides in Drinking Water from Drilled Bedrock Wells: Correlation to Geology and Bedrock Radioactivity and Dose Estimation," Radiation Protection Dosimetry, Vol. 102, No. 3, 2002, pp. 249-258.

http://dx.doi.org/10.1093/oxfordjournals.rpd.a006093

[15] Environmental Measurements Laboratory (EML), "Reference Title," US Department of Energy, Washington DC, 1990.

[16] K. Yanagisawa, Y. Muramatsu and H. Kamada, "Tracer Experiments on the Transfer of Technetium from soil to Rice and Wheat Plants," Radioisotopes, Vol. 41, 1992, pp. 397-402.

[17] F. W. Whicker, T. G. Hinton, K. A. Orlandini and S. B. Clark, "Uptake of Natural and Anthropogenic Actinides in Vegetable Crops Grown on a Contaminated Lake Bed," Journal of Environmental Radioactivity, Vol. 45, 1999, pp. 1-12.

http://dx.doi.org/10.1016/S0265-931X(98)00076-9 
[18] S. Harb, "On the Human Radiation Exposure as Derived from the Analysis of Natural and Man-Made Radionuclides in soil," Ph.D. Dissertation, Institute for Radiation
Protection and Radioecology, ZSR, Hannover University, Hannover, 2004. 